\title{
A kilencvenéves Széll Kálmán dr. köszöntése
}

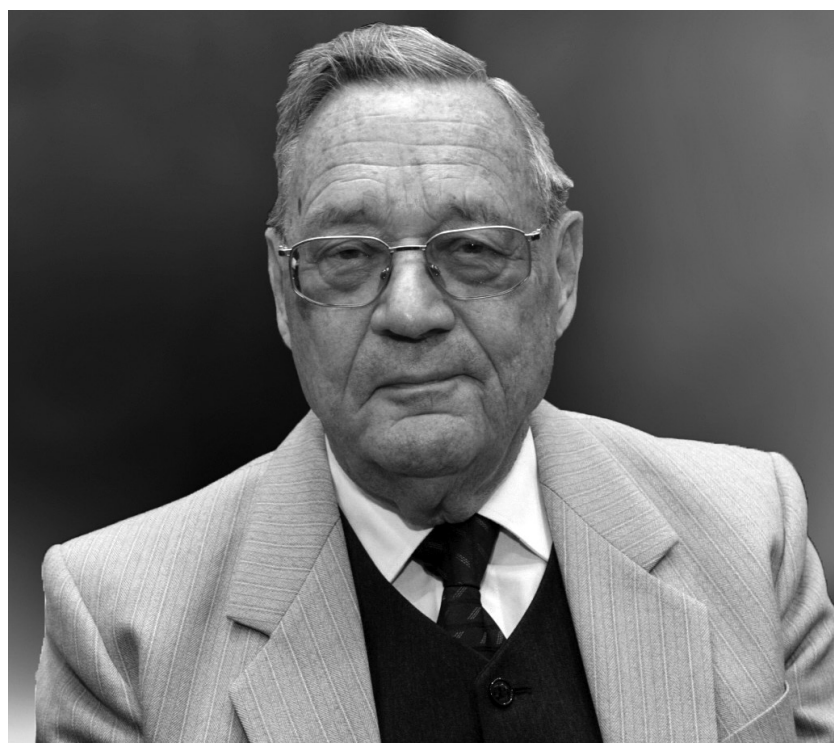

Bizony, Széll Kálmán professzor ez évben 90 éves! A szépkorú orvos gazdag életpályája tálcán kínálja a könnyed tárgyszerú visszaemlékezést, bemutatva annak gazdag ívét, de gyanítható, hogy az Öt ismerő kolléga annak minden fontos állomását ismeri, ha mégsem, azt a világhálón megismerheti, az életrajti adataitól a számos kitüntetéséig, beleértve a szakmai, társadalmi és egyházi elismeréseket.

Kissé nehezebb út is választható. Egy életpálya szubjektív bemutatása. Ez talán jobban tükrözi az orvos választott életútja fordulóinak okait, értelmét és eredményeit.

Széll Kálmán, a kiváló orvosprofesszor, orvos szervező, az orvosetikai tudomány bizonyítottan jó és kritikus ismerője, Szombathely díszpolgára, aki hitét soha nem rejtette véka alá - de azzal sohasem kérkedve -, a sors által adományozott, hosszú és hála Istennek testben és szellemben egyaránt irigyelhető kondícióban él. A mögötte álló kilencven év könnyen osztható stációkra.

Ifjúságáról bájosan ír az „Erőméz” című könyvében, amely egy hosszú élet hozadéka, változatosan, sok öniróniával füszerezett ars poeticája, azaz emberi hitvallása, az élet feladataira vonatkozó nézeteinek összefoglalása. Könyvében és számos visszaemlékezésében boldog, kiegyensúlyozott gyermek- és ifjúságkoráról számol be. A mai értelemben csonka családban, de szeretettel övezve nőtt fel. Szépen és plasztikusan ír kőszegi, majd nagyváradi tanulmányairól. A viszonylagos szegénység elle- nére, lelkiekben gazdag, de szigorú környezetben nevelkedve, jó szívvel gondol vissza gyermek- és serdülőéveire. Nyilván ebben segítette ikertestvére, akivel „sziámi ikreknek" tekinthetők. Útjaik később elváltak, de a kontinensek csak fizikálisan választották el a két profeszszort.

Orvosi pályáját megelőző budapesti egyetemi tanulmányait sem könnyư időszakban végezhette (háborút követő szegénység, szerény szülői segítség), de kitűnő szorgalommal és eredménnyel tette. Utólag ugyancsak derűsen megélt, elfogadó élményként maradt meg medikusélete. Ahogy egyszer fogalmazott: „Vágyainkat csak lebetôségeink határáig engedjük kibontakozni.”

Orvosként hazatért leendő fönöke felkérésére, szerencsés időben és jó helyen kezdte sebészi pályáját Szombathelyen. Szabolcs Zoltán professzor személyében egyetemi szintű elméleti és gyakorlati képzést kapott, így a fiatal orvos európai kitekintésû sebészeti műhelybe került.

Korán felismerte a fájdalom hatékony csillapításának szükségességét, és azt, hogy a mütét körüli, a mütőasztalon kívüli szakszerű ellátás, a kritikus állapotban lévő betegek intenzív kezelése sok életet menthet meg. Az újra fogékony fiatal orvos ezt az utat választotta. Szisztematikus felkészülés és támogató környezete segítségével országunkban igen korán vidéken, Szombathelyen intenzív betegellátó részleg, majd osztály létesült.

Mindig hangsúlyt fektetett arra, hogy orvosi tapasztalatait írásba is foglalja. Eredményei alapján hamarosan a szakma egyik legkiemelkedőbb hazai szaktekintélyének értékelték. Hosszú évtizedekig Szombathelyről szervezte és irányította az intenzív betegellátást, részben az illetékes szakmai kollégium elnökeként, részben az országos intézet vezető helyetteseként.

Nem általános, sőt inkább rendhagyó, hogy életkora haladásával időben felismerte, hogy a szikét és az intenzív orvoslást a zeniten és nem a csillaghullás idején kell abbahagyni. Ez bölcs emberre vall...

Orvosi tapasztalatait az egészségügyi felsőoktatásban máig tartóan kamatoztatja. A tudás és tapasztalat átadását mindig is kedvelő orvos ezt örömmel és hallgatósága nagy megelégedettségére teszi.

Mint a kritikus állapotban lévő betegek ellátásáért felelôs vezetőt, mindig izgatta a fájdalom, a szorongás, a kiszolgáltatottság, a halálfélelem, a halál közeli állapot és a sokszor legyőzhetetlen vagy értelmetlen halál etikai kérdései. Bizonyára ezek az élmények vezettek az idősödő 
orvos etikai véleményének irodalmi feltárásához. Évtizedek óta hallgatják előadásait és olvassák orvosok, ápolók, szülésznők és védőnők egyetemi jegyzetét és számos releváns tudományos tanulmányát.

Elkötelezett és mélyen vallásos hite messze a rendszerváltás előtt, a Rákosi-, majd a Kádár-korszakban jól ismert volt. Megtürték nézeteit, mert bástyája, az országon túli szakmai megbecsülése a rendszerrel, de mindenkivel szemben megvédte Öt.

Nem élt vissza a rendszerváltás hajnalán kínálkozó politikai karrier lehetőségeivel. Nyilvánvalóan évtizedes tapasztalatai azt sugallták, lehetnek környezetében politikai „könnyúlovasok”, akik az Ố tekintélyét meglovagolva szeretnék sajátjuknak kisajátítani. Ebben is realistaként visszafogott szerepet vállalt. Míg kellett, a keresztény értékrendnek megerôsítésére aktívan politizált, de nem választotta az etikai normáit meghaladó politikai hatalmi torzsalkodást, így inkább elhagyta a politikát.

Az éltes korú orvos egyházát gyermekkora óta szolgálja, és szívesen vállalja azokat a feladatokat, amelyek segítenek a kádári korban elveszetteknek hitüket visszaszerezni.

Így teljes a kilencven év. A sors biztos világnézeti alapokon álló etikai normákkal és szellemi képességgel áldotta meg. Egy fónemesi ág oldalszárnyán felnevelkedett, meggyőződéses és következetes hit birtokában kiválasztott úton, kivételesen magas ívú életpályát járva.
Ezeket az adományokat nem fecsérelte el, sohasem váltotta számára rögtön kamatozó kedvezó élethelyzetre. Lehetett volna itthon egyetemi orvosprofesszor, Svájcban, Kanadában vagy Németországban jól kereső orvos. Ő inkább maradt nyájánál. Talán érezte, csak itt, Szombathelyen nyerheti igazán el szakmája, betegei, közössége és egyháza nagyrabecsülését.

Széll Kálmán szerencsés, hiszen a hálás utókor önzetlen szakmai és közéleti tevékenységét még életében elhalmozza számos elismeréssel és kitüntetéssel.

Szombathelyen ma két Széll Kálmánt ismernek. Az elsőt, a jelentős politikust, a kiegyezés utáni pénzügyminisztert, majd felelős miniszterelnököt, és Széll Kálmánt, a miniszterelnök távoli oldalági rokonát, a köztiszteletben álló orvosprofesszort.

Az érdemeket nem osztják, azt ki kell érdemelni. De a jószolgálat nemcsak a népmesékben, - ugyan ritkábban hanem a valós életben is elnyeri jutalmát. Ỏ nem népmesei hős, hanem kivételesen elkötelezett és következetes mindenben, amiben meggyőződése szerint tenni lehet és tud a köz javára: az orvoslásban, az oktatásban, a tudományban, közéletben és a hitéletben. Röviden, Ö Szombathely Széll Kálmánja.

Szombathely, 2016.

Horváth Boldizsár dr. 